\title{
非接触式キャリパセンサの導入経験
}

\author{
王子エンジニアリング株式会社 米子事業部 坂 口 浩 昭
}

\section{Introduction of Non-contact Caliper Sensor}

Hiroaki Sakaguchi

Yonago Mill, Oji Engineering Co., Ltd.

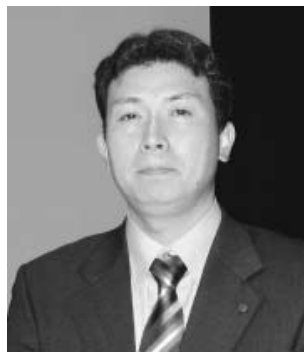

\begin{abstract}
There has been a large demand of the improvement in the thickness measurement for coated paper for many years. Especially for the higher grade white coated board, the contact caliper sensor is not a best fit due to its marking problem on the coat surface.

The improvement of the contact which physically contacts with paper has been struggled to avoid marking on the paper by changing the contact materials or contact pressure. But they deteriorated measurement accuracy and finally have not become the solution.

In May 2006, upgrade of QCS from Honeywell MXOpen to the latest DaVinci system was done for $3 \mathrm{M} / \mathrm{C}$ in Yonago Mill. At that timing, Honeywell had just announced the release of non-contact caliper sensor and we decided to apply this in this upgrade.

Honeywell's non-contact caliper sensor is the technology using laser to measure the thickness without contact and best fit for the sensitive paper surface. The caliper measurements for the grades for which have not been done before due to the marking would bring large benefit and effect.

In this article, the actual application of Honeywell's laser caliper sensor would be reported with measuring data.
\end{abstract}

分類 $: V_{2}$ 紙パルプ工程制御システム, $\mathrm{V}_{3}$ 紙パルプ工程計器およびセンサ

\section{1. はじめに}

従来から，塗工紙における紙厚測定はその測定方式を改 善する声が多かった。特に高級白板紙のように塗工表面が デリケートである紙にとって，接触式厚みセンサは紙表面 へのキズ入り問題を抱えていた。過去にも，物理的に紙に 接触する厚みセンサ接触子の最適化（接触子の材質の見直 し等）や，そのセンサ接触圧軽減による紙面へのキズ入り 回避に取り組んできたが, 結果はセンサ精度と相反するば かりで，それらの解決策にはならなかった。2006 年 5 月 に，米子工場 3 号マシンの BM 計をハネウェル社製 MXOpen システムから同社製 DaVinci システムへ更新し た。同時期に，ハネウェル社製非接触式厚みセンサ（レー ザキャリパセンサ）が発表され，この新センサを採用した。

非接触式キャリパセンサは，レーザ技術を使い，紙の表
面に触れることなく厚みを測定でき, 従来は紙へのキズ入 りにより使用できなかった銘柄での厚み測定を可能とし， その効果と利益を絶大なものにすると期待できる。

本稿では，ハネウェル社製レーザキャリパセンサの導入 経験とその測定状況について紹介する。

\section{3 号マシン概要及び BM システム構成}

2.13 号マシン概要

3 号マシンの概要を以下に示す。

·生産品目：高級白板紙

・ワイヤ幅：3,960 mm

• 抄速：220 580 m/分

$2.2 \mathrm{BM}$ システム構成

システム構成は，スキャナが 7 台接続され，オペレータ ステーション 9 台である。レーザキャリパセンサは， \#5 


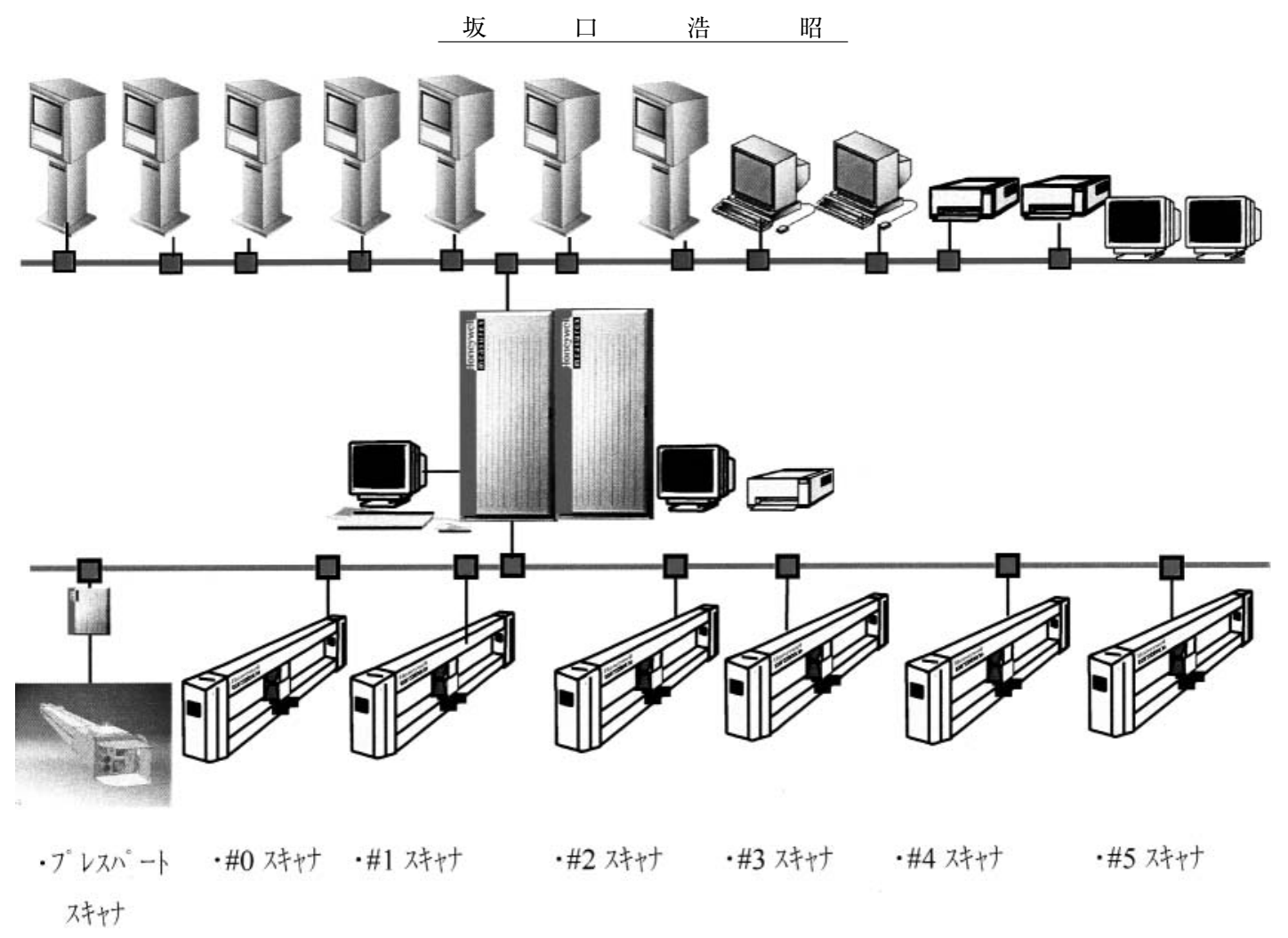

図 1 BM システム構成

・プレスパートスキャナ：ExPress 水分センサ

・\#0 スキャナ：坪量センサ, 水分センサ

・\#1 スキャナ：坪量センサ, 水分センサ, 厚みセンサ, カラーセンサ, IR 塗工量センサ

-\#2 スキャナ：坪量センサ, 水分センサ, IR 塗工量センサ

・\#3 スキャナ：坪量センサ，水分センサ，カラーセンサ，IR 塗工量センサ

・\#4 スキャナ：坪量センサ, 水分センサ, IR 塗工量センサ

・\#5 スキャナ：坪量センサ, 水分センサ, 厙みセンサ（レーザ及び接触式，，カラーセンサ, IR 塗工量センサ

スキャナ（リール前スキャナ）に設置されている。各スキ ヤナのセンサ構成を図 1 に示す。

\section{3. プリシジョン・レーザキャリパ・センサについて}

\section{1 センサ測定原理と概要}

ここでは，レーザキャリパセンサの測定原理と概要につ いて簡単に説明する。図 2 に示されるように三つのセンサ がそれぞれの距離を測定後, 紙の厚みを求める。

各レーザを使った測定原理は, 図 3 のように三角測量原
理に基づき上下へッドそれぞれのレーザセンサによりへッ ドから紙までの距離（Ltop，Lbot）を測定する。レーザ キャリパセンサに搭載された Z センサは，上下ヘッド間 の距離 Z を測定する。これらの結果より, 紙の厚み $\mathrm{Tx}$ は, 下記の式で表される。

$$
\mathrm{Tx}=\mathrm{Z}-(\text { Ltop }+ \text { Lbot })
$$

ここで使用される $Z$ センサは, セラミック素材を使っ たその機械構造により温度の影響を受け難くなっており, さらにペルチェクーラーにより温度制御がなされている。

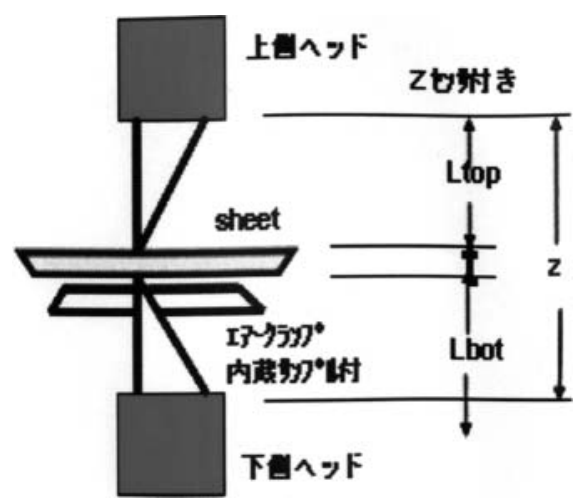

図 2 測定原理

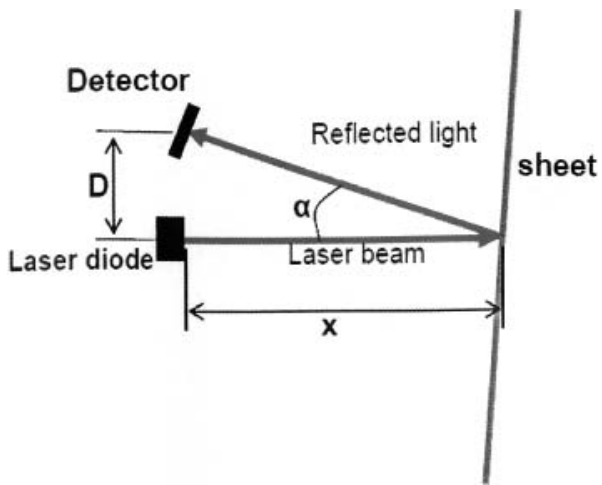

図 3 レーザ光を使った三角測量原理 
上下レーザスポット位置の違いによる厚み測定誤差を避け る為に, 測定位置で紙を水平に保つ為の機構（エアクラン プ）を装備している。

このエアクランプ機構は, 図 4 のドームと呼ばれている 円盤にある機構である。ドーム上のスリットからエアを吹 き出す構造だが，その吹出しスロットには特別のカーブが 施されていて, このカーブがコアンダ効果と呼ばれる現象 を発生させ，シート角度を紙に触れることなく水平に確保 し測定位置で安定させている（図 5)。

このエア機構によりレーザキャリパセンサは, オンライ ンでも安定した誤差の少ない測定をできる構造になってい る。

\section{4. センサ設置}

\section{1 センサ取付け作業}

レーザキャリパセンサは, 7 本フレーム中の＃５スキャ ナに設置した。； 5 スキャナは，リール前に設置されてお り, そのセンサヘッドは, 6 センサまでが内部搭載可能で ある。今回レーザキャリパセンサはシステムの設置後の取 り付けとなったが, 簡単に取り付ける事ができ特別な作業 は必要としなかった。

\section{2 センサ調整}

取り付け後のセンサ調整として, センサアライメントと センサキャリブレーション及びエアクランプのエア流量調 整が行われる。まずセンサアライメントであるが，以下の 2 点の調整を行う。

(1) 紙厚測定位置での紙が水平に最適な位置決め

(2) 上側及び下側のレーザスポットが測定位置で同一点 となるような位置決め

(1)の調整方法は，オフラインで紙をセンサ上に置きエア クランブ機構が紙を測定している状態でレーザセンサの位 置を $\mathrm{MD}$ 方向と $\mathrm{CD}$ 方向に移動させ，測定に適切な位置 を確認する。ただし, オンラインではこの適切な位置を再 調整が必要な場合もある。(2)調整方法は片側のセンサの 調整位置が決まった後で，もう片方のセンサの位置決めを 調整ツールにより測定位置を合わせる。

つぎにセンサキャリブレーションであるが，その目的は 絶対值をLVDTにて測定し, 相対的なセンサである上下 のレーザ及び Z センサの信号を測定可能な状態にするこ とである。

\section{5. 測定状況の把握}

\section{1 エアクランプ機構の有効性の確認}

最初にエアクランプ圧 $15 \mathrm{psi}(0.103 \mathrm{MPa})$ の条件で厚 み測定を行った。表示プロファイルは $10 \mathrm{~mm} /$ スライスの ミニスライスプロファイルである。図 6 上段に表示されて いるのはレーザキャリパ(青) と接触式キャリパセンサ (緑) のプロファイルを表示したものである。測定は同時に行い 接触式と非接触式が比較できるようにした。結果は, 非常 に相関の高いプロファイル（ $\pm 1.9 \mu \mathrm{m}$ のばらつき）とな った。図 6 下段のプロファイルは, レーザと接触式のスラ イス毎の差分を表示したプロファイルである。図7は，エ

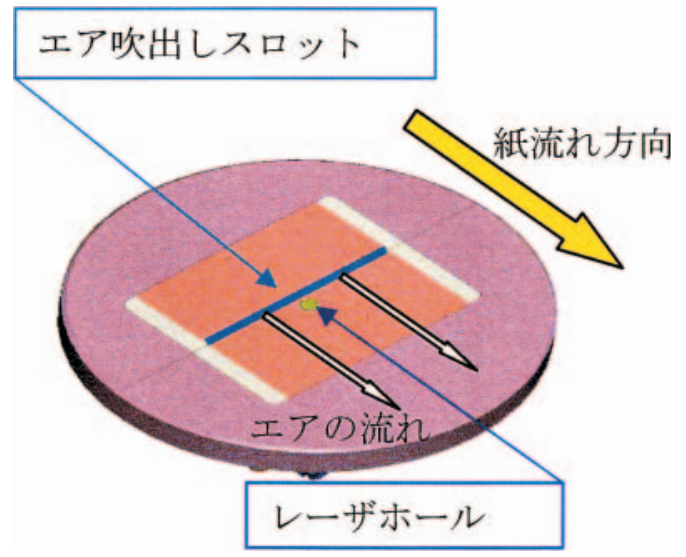

図 4 ドーム

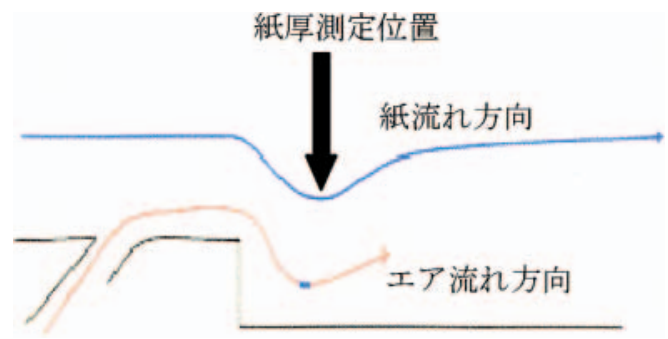

図 5 エアクランプ機構の原理

アクランプの効果を確認する為に，エアを止めた状態でレ ーザと接触式の測定值の比較を行ったプロファイルを表示 したものである。上段がその比較プロファイル $( \pm 3.3 \mu \mathrm{m}$ のばらつき）であるが，エアクランプ機構を使った方が， より相関が取れている事がわかり，機構の測定值精度への 有効性を確認できた。

しかしながら，テスト段階でひとつの問題が発生した。 非接触で紙面を測定位置で安定させるエアクランプ機構で あるが，厚紙を抄造時，時折塗工面の塗料がドームに付着 し，その後，硬化した付着塗料により紙面にキズをつけて しまう不具合が発生した。

\section{2 エアクランプ機構の改善}

この対策としてボルテックスタイプのエアクランプ機構 （写真 1）を変更した。このエアクランプ機構のエアの流 れは，写真 2 に示す。

エアクランプ圧を $10 \mathrm{psi}(0.07 \mathrm{Mpa})$ に設定し, 再度テ ストを実施した。図８は，そのテストにて得た測定プロフ アイルデータである。前回, キズ入りを発生させてしまっ たが, 接触式と相関があったコアンダタイプのエアクラン プ機構を使った測定結果と比較してほぼ同様の相関を確認 することができた。また，エアクランプ機構をボルテック スタイプへ変更した後では, 紙面へのキズ入りは発生しな かった。

\section{6. 今後の展開}

これまでのテストした品種では, 非接触式レーザキャリ パセンサは接触式キャリパセンサとの高い相関を確認する 

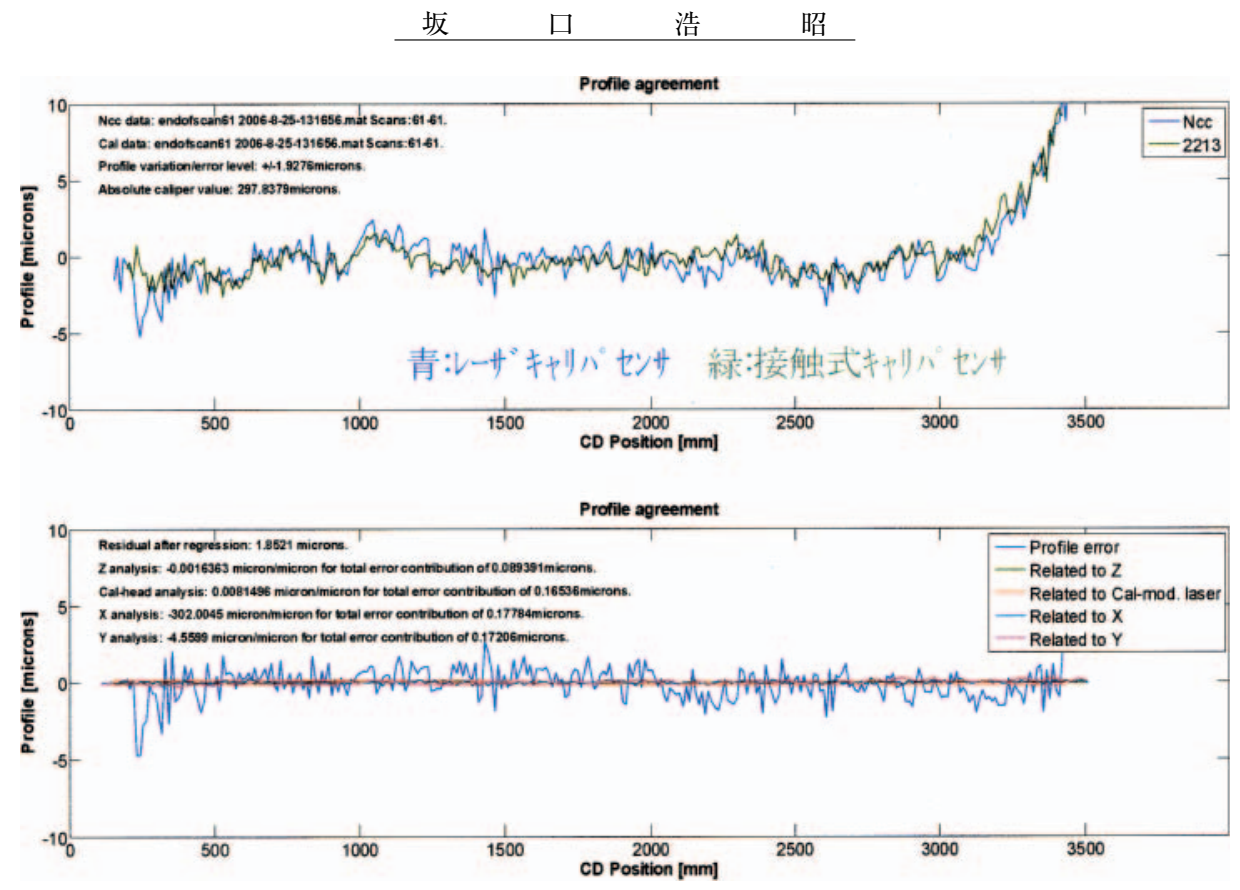

図 6 エアクランプ圧 $15 \mathrm{psi}$
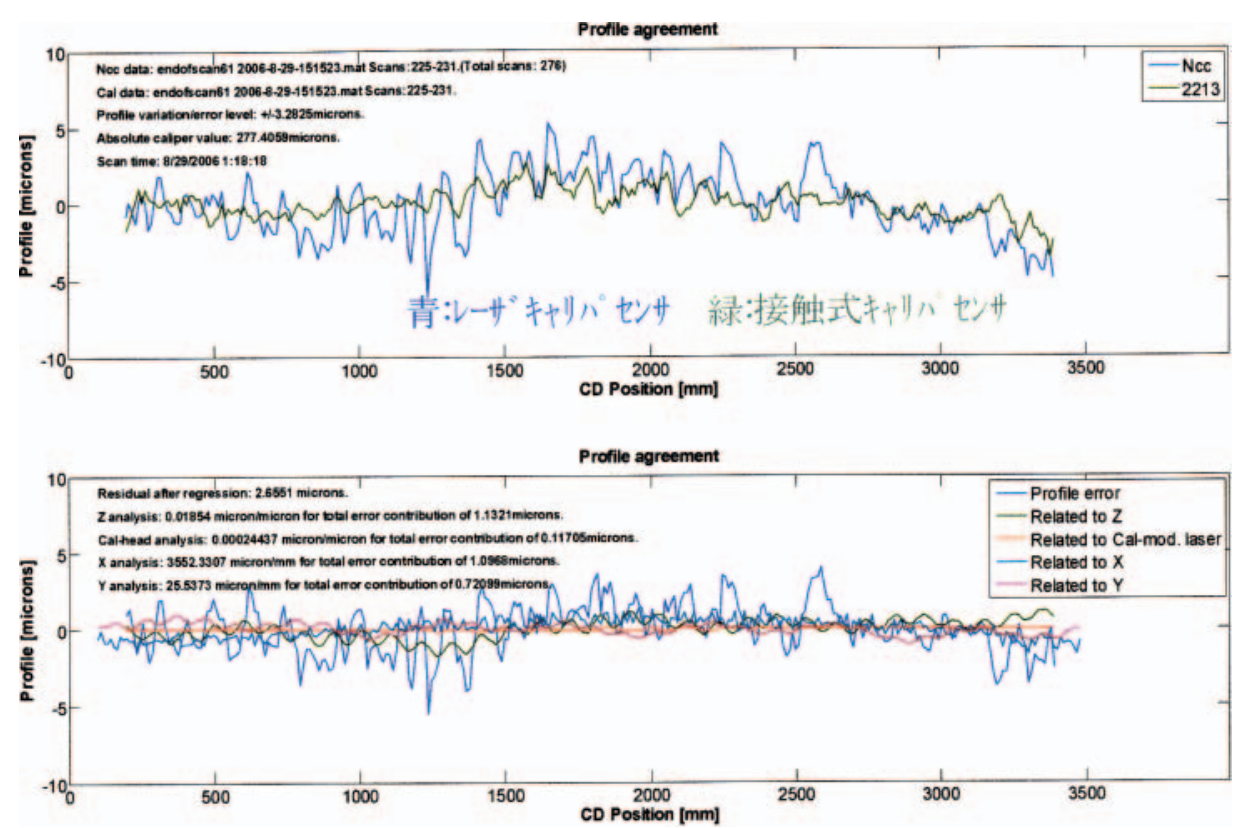

図 7 エアクランプ圧 0 psi（エアクランプ機構未使用）

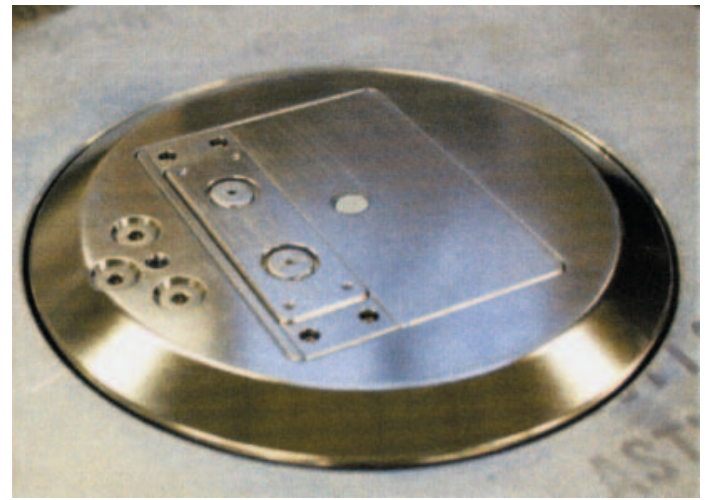

写真 1 ボルテックスタイプ (エアクランプ機構)

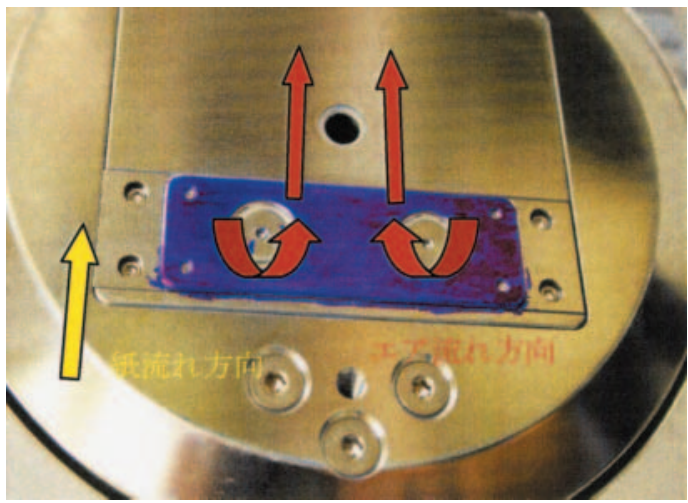

写真 2 ボルテックスタイプ (エア流れ方向) 

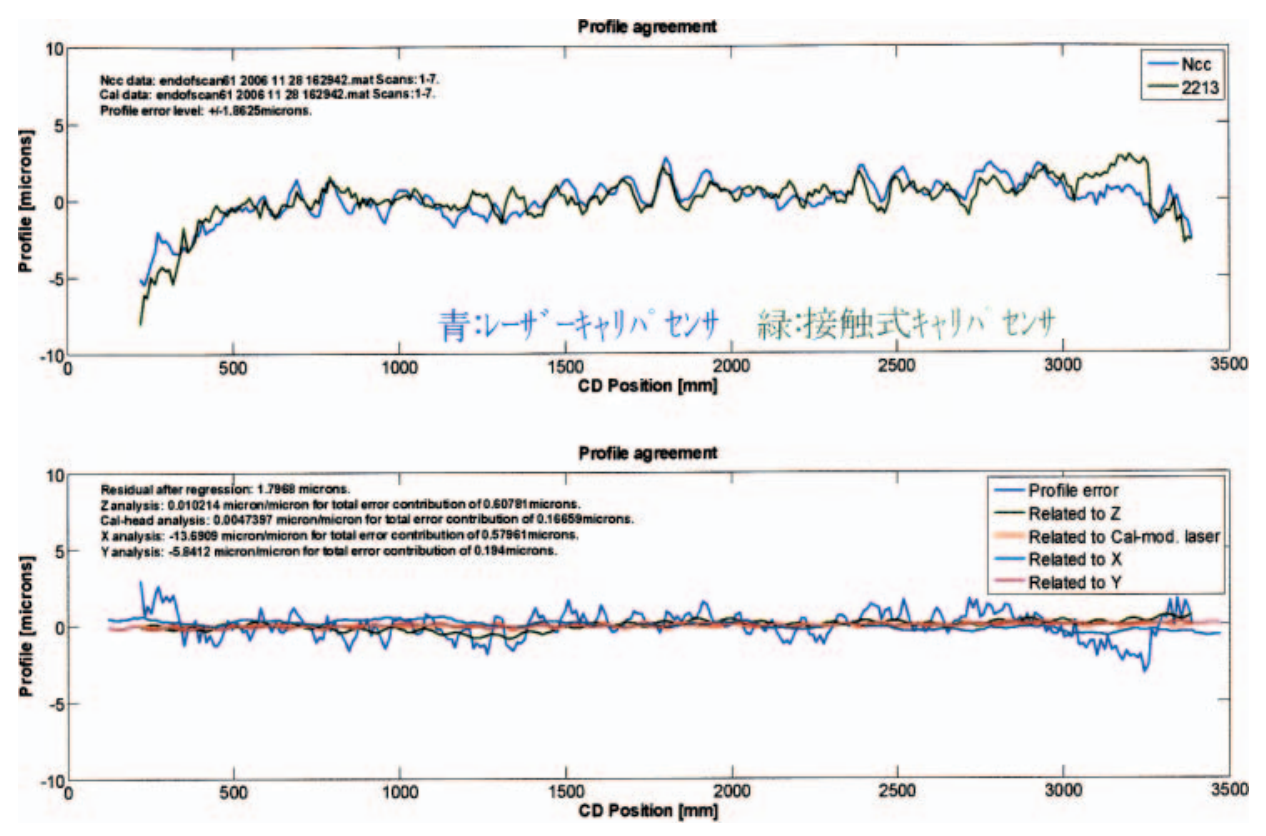

図 8 ボルテックスタイプ エアクランプ圧 $10 \mathrm{psi}$

ことができた。エアクランプ機構による紙面へのキズ入り についてはボルテックス式のエアクランプ機構を採用して からは発生していない。

3 号マシンで抄造している紙は，塗工表面がデリケート である品種が多く，もはや接触式のキャリパセンサでは品 質と製造効率を改善することはほぼ限界であった。今まで は接触式では測定できない品種においての調整やグレード チェンジには，多くの時間を費やしていた。しかし，レー
ザキャリパセンサによってグレードチェンジの時間短縮が 可能となった。今後も積極的に，レーザキャリパセンサを 活用し, 品質と製造効率を改善取り組んでいきたいと考え ている。

最後になりましたが，レーザキャリパセンサ導入と導入 後の改善にご協力をいただいたハネウエルジャパン株式会 社の皆様に感謝したい。 